\title{
A Crystallographic and DFT Study on a NHC Complex of
}

\section{Niobium Oxide Trifluoride}

\author{
Marco Bortoluzzi ${ }^{\text {a }}$, Eleonora Ferretti ${ }^{\text {b }}$, Fabio Marchetti ${ }^{\text {b, }}$, Guido Pampaloni ${ }^{\text {b }}$, \\ Stefano Zacchini $^{\mathrm{c}}$
}

\footnotetext{
${ }^{a}$ Ca' Foscari Università di Venezia, Dipartimento di Scienze Molecolari e Nanosistemi, Via Torino 155, I-30175 Mestre (Venezia), Italy

${ }^{b}$ Università di Pisa, Dipartimento di Chimica e Chimica Industriale, Via Moruzzi 13, I-56124 Pisa, Italy

c Dipartimento di Chimica Industriale "Toso Montanari”, Università di Bologna, Viale Risorgimento 4, I-40136 Bologna, Italy
}

Received......; accepted

\footnotetext{
* Corresponding author. Tel.: +390502219245.E-mail address: fabio.marchetti1974@unipi.it Webpage: http://www.dcci.unipi.it/fabio-marchetti.html

$\S$ Present address: Georg-August-Universität Göttingen, Institut für Anorganische Chemie, Tammannstrasse 4, D-37077 Göttingen, Germany.
} 


\begin{abstract}
The complex $\left[\mathrm{NbOF}_{3}(\mathrm{Ipr})\right]_{2}$, $\mathbf{1}$, was afforded in crystalline form by the reaction of $\mathrm{NbF}_{5}$ with the bulky NHC ligand 1,3-bis(2,6-diisopropylphenyl)imidazol-2-ylidene (IPr), in toluene by slow contact with moisture air. The molecular structure of $\mathbf{1}$ was ascertained by X-ray diffraction, providing the first example of a dinuclear $\mathrm{NbOF}_{3}$ derivative and also a rare case of niobium compound with a monodentate NHC. A DFT investigation has shown that the $\mathrm{Nb}-\mathrm{C}$ bond consists of a weak $\mathrm{NHC}$ to $\mathrm{Nb} \sigma$ donation, reinforced by an electrostatic contribution presumably favored by the presence of the ancillary fluoride ligands. The computed enthalpy for the dissociation of one Ipr from 1 is ca. $36 \mathrm{kcal} \mathrm{mol}^{-1}$. The presence of bulky 2,6-diisopropylphenyl substituents on the carbene ligand has negligible influence on the $\mathrm{Nb}-\mathrm{C}$ bond, as highlighted by DFT analyses on simplified models.
\end{abstract}

Keywords: Niobium Pentafluoride, Niobium Oxide Fluoride, NHC ligand, Coordination Chemistry, High Valent Metal Complexes

\title{
1. Introduction
}

$N$-heterocyclic carbenes (NHC) have become ubiquitous ligands in organometallic chemistry, providing unique properties to the resulting metal complexes [1]. NHC chemistry has been developed mainly with reference to low and medium valent metals, belonging to middle to late transition groups, whereas NHC systems based on early transition and high valent metals have been much less investigated [2,3]. In particular, only few niobium-NHC complexes have appeared in the literature up to now [4,5] and, in general, NHC adducts of elements in oxidation state above +4 are rather rare $[3 a, 6]$.

In the last decade, we have contributed to the advance of the chemistry of niobium pentahalides [7], being stimulated by the attractive properties of these compounds, such as cheapness, low 
toxicity associated with the element niobium and interesting outcomes of metal directed organic transformations $[7 \mathrm{~b}-\mathrm{e}, 8]$.

The main limitation in the use of niobium pentahalides in catalytic reactions is probably represented by their high moisture sensitivity, which increases on moving from the fluoride to the iodide down the halogen group [7d]. In order to supply relative inertness to water, the introduction of an oxido group in replacement of two halide ligands is a possible strategy. This is a well defined reaction for niobium pentachloride [9], and the chemistry of $\mathrm{NbOCl}_{3}$ has been explored to some extent [10]. In agreement with the $\mathrm{Nb}$-halogen bond energies scale [11], the synthetic procedures leading to $\mathrm{NbOF}_{3}$ are more prohibitive [12], and the coordination chemistry of $\mathrm{NbOF}_{3}$ has been relatively undeveloped [13]. Levason and Reid and coworkers have recently proposed a straightforward strategy to access mononuclear $\mathrm{NbOF}_{3}$ adducts with oxygen or nitrogen donors, by treatment of the $\mathrm{NbF}_{5} /$ ligand system with hexamethyldisiloxane in the presence of acetonitrile [10a]. The alternative synthesis of $\mathrm{NbOF}_{3}$ complexes from $\mathrm{NbF}_{5}$ derivatives by addition of water seems to be a non effective method, the neutral ligand being normally displaced to give $\left[\mathrm{NbF}_{6}\right]^{-}$ salts $[13 \mathrm{a}, 14]$.

Herein, we report on the formation and the structural characterization of a dinuclear $\mathrm{NbOF}_{3}$ adduct with the bulky NHC 1,3-bis(2,6-diisopropylphenyl)imidazol-2-ylidene), Ipr, obtained by means of slow diffusion of moist air into a $\mathrm{NbF}_{5} / \mathrm{Ipr}$ mixture. In a similar manner, the complex $\mathrm{WO}_{2} \mathrm{Cl}_{2}(\mathrm{Ipr})$ was previously obtained from $\mathrm{WOCl}_{4}$ and $\mathrm{Ipr}[3 \mathrm{a}]$.

\section{Results and Discussion}

The reaction of $\mathrm{NbF}_{5}$ with 1,3-bis(2,6-diisopropylphenyl)-imidazol-2-ylidene (Ipr), in dry toluene, affords the mononuclear complex $\mathrm{NbF}_{5}(\mathrm{Ipr})[15,4 \mathrm{~b}]$. Once isolated in the solid state, $\mathrm{NbF}_{5}(\operatorname{Ipr})$ exhibits moderate air stability if compared to other group 5 pentafluoride complexes [16]. Instead, the toluene reaction mixture is significantly more moisture sensitive, and all our attempts of 
crystallization led to the isolation of small amounts of the complex $\left[\mathrm{NbOF}_{3}(\operatorname{Ipr})\right]_{2}, \mathbf{1}$, see Scheme 1. The formation of $\mathbf{1}$ appears to be the result of the action of adventitious water, in spite of the use of anhydrous reaction conditions.

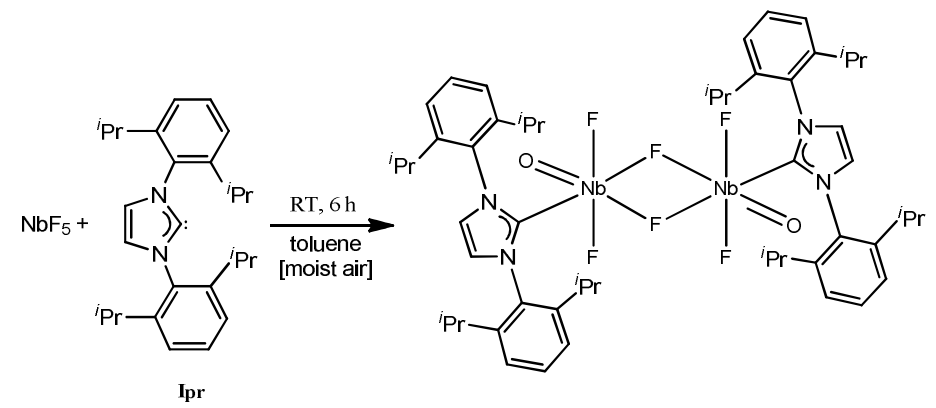

Scheme 1. Synthesis of a niobium(V) oxido-fluoride NHC complex.

Our attempts to reproduce the synthesis of $\mathbf{1}$ by alternative methods, i.e. treatment of $\mathrm{NbF}_{5} / \mathrm{Ipr}$ with, respectively, $\mathrm{O}\left(\mathrm{SiMe}_{3}\right)_{2}$ or $\mathrm{H}_{2} \mathrm{O}$, led to the formation of mixtures of non identified products. A similar outcome was achieved by using the Levason and Reid's approach (treatment of $\mathrm{NbF}_{5}$ with $\mathrm{NHC} / \mathrm{O}\left(\mathrm{SiMe}_{3}\right)_{2} / \mathrm{MeCN}$, see introduction) [10a]. The insolubility of compound $\mathbf{1}$ prevented NMR characterization. The IR spectrum (in the solid state) displays a band at $944 \mathrm{~cm}^{-1}$, attributed to the $\mathrm{Nb}=\mathrm{O}$ moiety [10a]. The calculated IR absorption due to the weak $\mathrm{Nb}-\mathrm{C}$ bond falls around $350 \mathrm{~cm}^{-1}$.

X-ray diffraction analysis was carried out on a single crystal and allowed to ascertain the molecular structure. Compound $\mathbf{1}$ is a dinuclear compound composed of two distorted octahedral $\mathrm{Nb}(\mathrm{V})$ units sharing one edge (Figure 1 and Table 1), thus exhibiting an unprecedented $\mathrm{Nb}_{2}(\mathrm{O})_{2} \mathrm{X}_{4}(\mu-\mathrm{X})_{2}(\mathrm{~L})_{2}$ framework $(\mathrm{X}=$ any halogen; $\mathrm{L}=$ neutral ligand $)$. The terminal oxido and NHC carbene ligands occupy equatorial positions respect to the $\mathrm{Nb}_{2}(\mu-\mathrm{F})_{2}$ ring, in a relative pseudo-trans orientation. The $\mathrm{Nb}_{2}(\mu-\mathrm{F})_{2}$ ring is asymmetric $[\mathrm{Nb}(1)-\mathrm{F}(1) \quad 2.3193(12) \AA$; $\mathrm{Nb}(1)-\mathrm{F}(2)$ 1.9952(12) $\AA ; \mathrm{Nb}(2)-\mathrm{F}(1)$ 1.9915(12) $\AA$; $\mathrm{Nb}(2)-\mathrm{F}(2)$ 2.3632(13) $\AA]$, due to the stronger trans influence of the terminal oxido ligand compared to the NHC carbene. The same 
ring is perfectly planar [mean deviation from the least squares plane $0.0105 \AA$ ], and also the $\mathrm{O}(1)$ and $\mathrm{O}(2)$ oxido ligands, and $\mathrm{C}(1)$ and $\mathrm{C}(31)$ carbene atoms lie on the same plane [mean deviation from the least squares plane $0.0175 \AA]$. The $\mathrm{Nb}(1)-\mathrm{O}(1)[1.6989(15) \AA]$ and $\mathrm{Nb}(2)-\mathrm{O}(2)$ $\left[\begin{array}{ll}1.6942(15) & \AA\end{array}\right]$ distances are slightly shorter than those observed in mononuclear $\mathrm{NbOF}_{3}$ complexes [10a]. The $\mathrm{Nb}(1)-\mathrm{C}(1)[2.339(2) \AA]$ and $\mathrm{Nb}(2)-\mathrm{C}(31)[2.322(2) \AA]$ distances are significantly longer than both $\mathrm{Nb}(\mathrm{V})$-alkylidene moieties $[17,4]$ and even classical $\mathrm{Nb}(\mathrm{V})$-alkyl $\sigma$ bonds [18]; as a comparison, the longest $\mathrm{Nb}-\mathrm{C}$ distance in $\mathrm{NbCl}_{2} \mathrm{Me}_{3}$ measures 2.152(4) $\AA$ [18a]. A similar situation was found in the unique $\mathrm{Nb}(\mathrm{V})-\mathrm{NHC}$ complex crystallographically characterized to date, i.e. $\mathrm{NbCl}_{5}(\mathrm{IPr})$ [4], featuring a long Nb-carbene distance [2.396(12) $\AA$ ]. The $\mathrm{Nb}(\mathrm{IV})-\mathrm{C}$ lengths in $\mathrm{NbOX}_{2}(\mathrm{NHC})_{2}(\mathrm{X}=\mathrm{Cl}, \mathrm{Br})$ were found to be around $2.32 \AA$ [4c], while the $\mathrm{Nb}(\mathrm{III})-\mathrm{C}$ lengths in the chelating $\mathrm{NHC}$ adduct $\left[\left(\mathrm{C}-\mathrm{N}-\mathrm{C}^{\prime}\right) \mathrm{NbCl}_{3}(\right.$ thf $\left.)\right], \mathrm{C}-\mathrm{N}-\mathrm{C}^{\prime}=2,6-$ bis(imidazolylidene)pyridine, were found to be around $2.20 \AA$ [5a]. These data suggest that, in general, the binding of monodentate $\mathrm{NHC}$ ligands to $\mathrm{Nb}(\mathrm{V})$ complexes is relatively weak. The carbene atoms of $\mathrm{NbOF}_{3}(\mathrm{Ipr})$ display $\mathrm{C} \cdots \mathrm{F}[2.819-2.873 \AA]$ and $\mathrm{C} \cdots \mathrm{O}[2.930-3.067 \AA]$ contacts with the terminal $\mathrm{F}$ and $\mathrm{O}$ ligands, respectively, which are within the sums of the van der Waals $\operatorname{radii}[\mathrm{sum}=3.17 \AA$ for $\mathrm{C} \cdots \mathrm{F}$ and $3.22 \AA$ for $\mathrm{C} \cdots \mathrm{O}][19]$. Analogous interactions were observed in other $\mathrm{d}(0)$ high valent metal chlorides with monodentate NHC ligands, and have been speculated to be the consequence of metal-carbon $\pi$ bonding. This would be possible in spite of the formal absence of electrons at the metal centre, due to the electron density on the Cl-ligands [3a,6a,20]. 


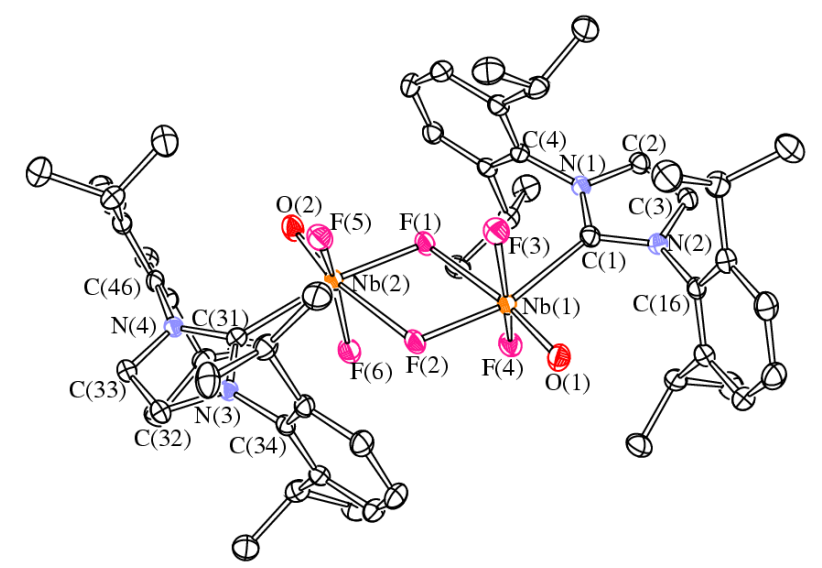

Figure 1. Molecular structure of $\left[\mathrm{NbOF}_{3}(\mathrm{Ipr})\right]_{2}$, 1, with key atoms labeled. Displacement ellipsoids are at the $50 \%$ probability level.

Table 1.Selected bond distances $(\AA)$ and angles $\left(^{\circ}\right)$ for $\mathbf{1}$.

\begin{tabular}{llll}
\hline $\mathrm{Nb}(1)-\mathrm{C}(1)$ & $2.339(2)$ & $\mathrm{Nb}(2)-\mathrm{C}(31)$ & $2.322(2)$ \\
$\mathrm{Nb}(1)-\mathrm{O}(1)$ & $1.6989(15)$ & $\mathrm{Nb}(2)-\mathrm{O}(2)$ & $1.6942(15)$ \\
$\mathrm{Nb}(1)-\mathrm{F}(1)$ & $2.3193(12)$ & $\mathrm{Nb}(2)-\mathrm{F}(2)$ & $2.3632(13)$ \\
$\mathrm{Nb}(1)-\mathrm{F}(2)$ & $1.9952(12)$ & $\mathrm{Nb}(2)-\mathrm{F}(1)$ & $1.9915(12)$ \\
$\mathrm{Nb}(1)-\mathrm{F}(3)$ & $1.9015(12)$ & $\mathrm{Nb}(1)-\mathrm{F}(5)$ & $1.9084(12)$ \\
$\mathrm{Nb}(1)-\mathrm{F}(4)$ & $1.9171(12)$ & $\mathrm{Nb}(1)-\mathrm{F}(6)$ & $1.9073(12)$ \\
$\mathrm{C}(1)-\mathrm{N}(1)$ & $1.363(3)$ & $\mathrm{C}(31)-\mathrm{N}(3)$ & $1.356(2)$ \\
$\mathrm{C}(1)-\mathrm{N}(2)$ & $1.363(3)$ & $\mathrm{C}(31)-\mathrm{N}(4)$ & $1.365(3)$ \\
$\mathrm{N}(1)-\mathrm{C}(2)$ & $1.382(2)$ & $\mathrm{N}(3)-\mathrm{C}(32)$ & $1.388(2)$ \\
$\mathrm{N}(2)-\mathrm{C}(3)$ & $1.388(2)$ & $\mathrm{N}(4)-\mathrm{C}(33)$ & $1.387(2)$ \\
$\mathrm{C}(2)-\mathrm{C}(3)$ & $1.347(3)$ & $\mathrm{C}(32)-\mathrm{C}(33)$ & $1.349(3)$ \\
& & & \\
$\mathrm{O}(1)-\mathrm{Nb}(1)-\mathrm{F}(1)$ & $170.87(6)$ & $\mathrm{O}(2)-\mathrm{Nb}(2)-\mathrm{F}(2)$ & $167.45(6)$ \\
$\mathrm{C}(1)-\mathrm{Nb}(1)-\mathrm{F}(2)$ & $160.48(6)$ & $\mathrm{C}(31)-\mathrm{Nb}(2)-\mathrm{F}(1)$ & $168.21(6)$ \\
$\mathrm{F}(3)-\mathrm{Nb}(1)-\mathrm{F}(4)$ & $157.18(5)$ & $\mathrm{F}(5)-\mathrm{Nb}(2)-\mathrm{F}(6)$ & $154.87(6)$ \\
$\mathrm{F}(1)-\mathrm{Nb}(1)-\mathrm{F}(2)$ & $68.95(4)$ & $\mathrm{F}(1)-\mathrm{Nb}(2)-\mathrm{F}(2)$ & $68.08(4)$ \\
$\mathrm{Nb}(1)-\mathrm{F}(1)-\mathrm{Nb}(2)$ & $112.43(5)$ & $\mathrm{Nb}(1)-\mathrm{F}(2)-\mathrm{Nb}(2)$ & $110.51(5)$ \\
$\mathrm{Nb}(1)-\mathrm{C}(1)-\mathrm{N}(1)$ & $127.33(14)$ & $\mathrm{Nb}(2)-\mathrm{C}(31)-\mathrm{N}(3)$ & $127.19(14)$ \\
$\mathrm{Nb}(1)-\mathrm{C}(1)-\mathrm{N}(2)$ & $128.45(14)$ & $\mathrm{Nb}(2-\mathrm{C}(31)-\mathrm{N}(4)$ & $128.65(14)$ \\
$\mathrm{N}(1)-\mathrm{C}(1)-\mathrm{N}(2)$ & $103.85(17)$ & $\mathrm{N}(3)-\mathrm{C}(31)-\mathrm{N}(4)$ & $104.08(16)$ \\
$\mathrm{C}(1)-\mathrm{N}(1)-\mathrm{C}(2)$ & $111.69(17)$ & $\mathrm{C}(31)-\mathrm{N}(3)-\mathrm{C}(32)$ & $111.71(16)$ \\
$\mathrm{N}(1)-\mathrm{C}(2)-\mathrm{C}(3)$ & $106.44(17)$ & $\mathrm{N}(3)-\mathrm{C}(32)-\mathrm{C}(33)$ & $106.19(17)$ \\
$\mathrm{C}(2)-\mathrm{C}(3)-\mathrm{N}(2)$ & $107.07(17)$ & $\mathrm{C}(32)-\mathrm{C}(33)-\mathrm{N}(4)$ & $107.16(17)$ \\
$\mathrm{C}(3)-\mathrm{N}(2)-\mathrm{C}(1)$ & $110.94(17)$ & $\mathrm{C}(33)-\mathrm{N}(4)-\mathrm{C}(31)$ & $110.86(16)$ \\
\hline & & &
\end{tabular}

In order to shed light on structural aspects and, in particular, the nature of the $\mathrm{Nb}-\mathrm{C}$ bond in $\mathbf{1}$, we performed DFT calculations. A view of the calculated structure of $\mathbf{1}$ is shown in Figure 2, while relevant bonding parameters are given in Table 2, showing substantial agreement with the corresponding X-ray data. 


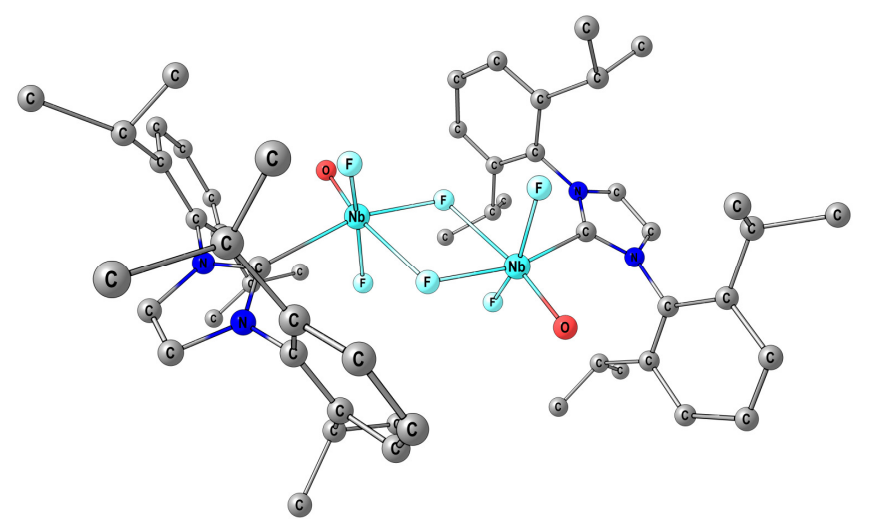

Figure 2. Calculated structure of $\left[\mathrm{NbOF}_{3}(\mathrm{Ipr})\right]_{2}, \mathbf{1}\left(\omega \mathrm{B} 97 \mathrm{X} / \mathrm{C}-\mathrm{PCM}, \mathrm{CH}_{2} \mathrm{Cl}_{2}\right.$ as implicit solvent). Hydrogen atoms have been omitted for clarity.

Table 2.Selected computed distances $(\AA)$ and angles $\left(^{\circ}\right)$ for $\left[\mathrm{NbOF}_{3}(\operatorname{Ipr})\right]_{2}, \mathbf{1} .^{21}$

\begin{tabular}{llll}
\hline & Lengths & & Angles \\
\hline $\mathrm{Nb}-\mathrm{C}$ & 2.328 & $\mathrm{C}-\mathrm{Nb}-\mathrm{O}$ & 97.5 \\
$\mathrm{Nb}-\mathrm{O}$ & 1.689 & $\mathrm{C}-\mathrm{Nb}-\mathrm{F}$ & $80.8,85.6$ \\
$\mathrm{Nb}-\mathrm{F}$ & $1.913,1.915$ & $\mathrm{C}-\mathrm{Nb}-\mathrm{F}$ & $93.7,160.5$ \\
$\mathrm{Nb}-\mathrm{F}$ & $2.005,2.366$ & $\mathrm{~F}-\mathrm{Nb}-\mathrm{F}$ & 67.2 \\
$\mathrm{Nb} \cdots \mathrm{Nb}$ & 3.642 & & \\
\hline
\end{tabular}

The computational analysis of the molecular orbitals has suggested that the $\mathrm{Nb}-\mathrm{C}$ bonds are purely $\sigma$-type in character. However, the overlap between $\mathrm{Nb}$ and $\mathrm{C}$ is quite scarce and can be observed only with reference to low energy molecular orbitals, i.e. HOMO-45 $(\varepsilon=-12.8 \mathrm{eV})$ and especially HOMO-100 $\left(\varepsilon=-15.4 \mathrm{eV}\right.$; as a reference, $\left.\varepsilon_{\text {НОмО }}=-9.2 \mathrm{eV}\right)$. The same molecular orbitals account for interactions of the $\mathrm{Nb}$ centers with the other atoms located in the inner coordination sphere (Figure 3). The small difference in Mulliken partial charge on the carbenic carbon in 1 with respect to the free ligand (0.056 a.u.) supports the idea that the $\mathrm{Nb}-\mathrm{C}$ bond consists of a weak $N H C$ to $N b \sigma$ donation. Notwithstanding, according to the calculated $\Delta \mathrm{H}=36.1$ $\mathrm{kcal} \mathrm{\textrm {mol } ^ { - 1 }}$ related to the dissociation reaction $\left\{\left[\mathrm{NbOF}_{3}(\mathrm{Ipr})\right]_{2} \rightarrow \mathrm{NbOF}_{2}(\mu-\mathrm{F})_{2} \mathrm{NbOF}_{2}(\mathrm{Ipr})+\mathrm{Ipr}\right\}$, the $\mathrm{Nb}-\mathrm{C}$ bond should be relatively strong ( $\omega \mathrm{B} 97 \mathrm{X} / \mathrm{C}-\mathrm{CPM}$ calculations). Indeed the bond appears reinforced by electrostatic ion-dipole interactions, presumably provided by the electronegative atoms (F) in the coordination sphere of the metal centre. As a matter of fact, several occupied molecular orbitals, whose energies fall in within the interval -11.4 to $-12.1 \mathrm{eV}$, show the presence of electron density on the formal $s p^{2}$ lone pairs belonging to the donor carbon 
atoms, and the participation of $\mathrm{Nb}$ atomic orbitals to these MOs is negligible (see for instance HOMO-12 in Figure 3).

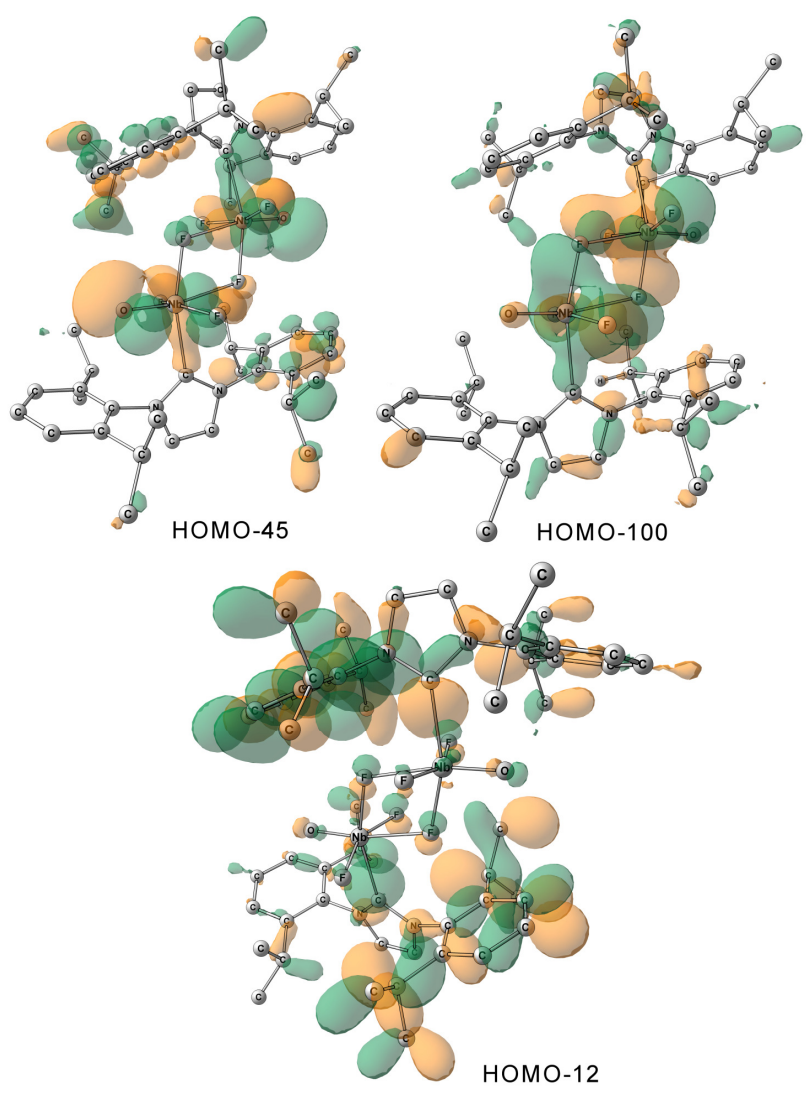

Figure 3. Plot of selected occupied $\mathrm{MOs}$ of $\left[\mathrm{NbOF}_{3}(\mathrm{Ipr})\right]_{2}$, 1. Surface isovalue $=0.02$ a.u. Hydrogen atoms have been omitted for clarity.

Finally, it should be noted that the $\pi^{*}$ orbitals of the NHC ligands do not meaningfully overlap with orbitals of the fluorine ligands. A comparable outcome has been achieved by performing the calculations on a hypothetical molecule (Ime) formally obtained from 1 by replacement of the 2,6diisopropylphenyl substituents with methyl groups, Chart 1.

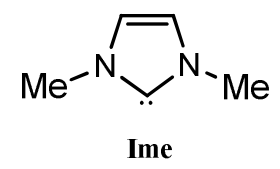

Chart 1. Diagram of the Me-substituted NHC

A view of this calculated molecule is depicted in Figure 4, showing a $39^{\circ}$ rotation of the NHC plane 
around the $\mathrm{Nb}-\mathrm{C}$ bond by comparison to 1 , probably due to the reduced encumbrance of the $\mathrm{NHC}$ groups. The computed $\Delta \mathrm{H}$ for the dissociation of one $\mathrm{NHC}$ ligand, $35.4 \mathrm{kcal} \mathrm{mol}^{-1}$, and the $\mathrm{Nb}-\mathrm{C}$ bond lengths, $2.296 \AA$, in $\left[\mathrm{NbOF}_{3}(\mathrm{Ime})\right]_{2}$ are very close to the corresponding values found for $\mathbf{1}$.

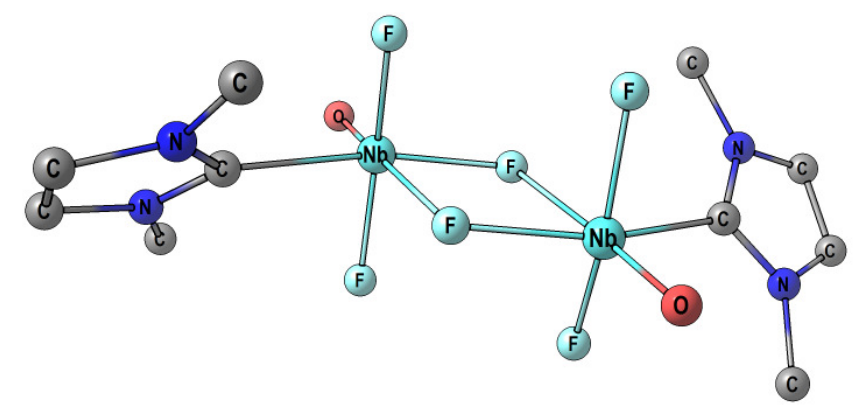

Figure 4. Calculated structure of $\left[\mathrm{NbOF}_{3}(\mathrm{Ime})\right]_{2}\left(\omega \mathrm{B} 97 \mathrm{X} / \mathrm{C}-\mathrm{PCM}, \mathrm{CH}_{2} \mathrm{Cl}_{2}\right.$ as implicit solvent). Hydrogen atoms have been omitted for clarity.

\section{Conclusions}

We have obtained a coordination compound of niobium oxide trifluoride with a monodentate NHC ligand, otherwise hardly accessible, from a $\mathrm{NbF}_{5} / \mathrm{NHC}$ reaction mixture undergoing slow hydrolysis. The product represents a rare example of a crystallographically characterized Nb-NHC system, and the first example of a niobium fluoride NHC complex. According to X-ray and DFT evidences, the niobium-carbene bond consists of a purely $\sigma$ covalent interaction reinforced by an electrostatic interaction. The structural characterization described herein contributes to the advance of the relatively undeveloped coordination chemistry of $\mathrm{NbOF}_{3}$, and to the knowledge of the relatively little investigated oxophilic metal halide-NHC bonding systems.

\section{Experimental}

4.1. General considerations. The reaction vessels were oven dried at $140^{\circ} \mathrm{C}$ prior to use, evacuated $\left(10^{-2} \mathrm{mmHg}\right)$ and then filled with nitrogen. $\mathrm{NbF}_{5}$ (Apollo Sci., 99.5\%) was sublimed and stored in sealed tubes under nitrogen. Ipr was prepared according to the published procedure [22], by using organic reactants (Apollo Sci.) of the highest purity available, and then stored under nitrogen. 
Solvents (Sigma-Aldrich) were distilled before use from appropriate drying agents. Once isolated, the product 1 was conserved in a sealed glass tube under nitrogen. Infrared spectrum was recorded at $298 \mathrm{~K}$ on a FT IR-Perkin Elmer Spectrometer, equipped with a UATR sampling accessory. Carbon, hydrogen and nitrogen analysis was performed on a Carlo Erba mod. 1106 instrument.

\subsection{Formation and isolation of $\mathrm{NbOF}_{3}(\mathrm{Ipr}), \mathbf{1}$.}

$\mathrm{NbF}_{5}(80 \mathrm{mg}, 0.426 \mathrm{mmol})$ was added to a solution of Ipr $(165 \mathrm{mg}, 0.426 \mathrm{mmol})$ in dry toluene $(15 \mathrm{~mL})$, and the mixture was stirred at room temperature for 18 hours. The resulting light orange solution was filtrated in order to remove some insoluble material, then it was concentrated under vacuum to ca. $2 \mathrm{~mL}$. Standing in the freezer $\left(-30{ }^{\circ} \mathrm{C}\right)$ for a period variable between one and two weeks resulted in the formation of a colorless crystalline material, corresponding to $\mathbf{1}(1 / 2$ toluene), in 5-10\% yield. Anal. calcd. for $\mathrm{C}_{61} \mathrm{H}_{80} \mathrm{~F}_{6} \mathrm{~N}_{4} \mathrm{Nb}_{2} \mathrm{O}_{2}$ : C, 61.00; $\mathrm{H}, 6.71 ; \mathrm{N}, 4.66$. Found: $\mathrm{C}, 61.05$; $\mathrm{H}, 6.63 ; \mathrm{N}, 4.58$. IR (solid state): $v=2962 \mathrm{w}-\mathrm{m}, 2870 \mathrm{w}, 1545 \mathrm{w}-\mathrm{m}, 1466 \mathrm{~m}, 1432 \mathrm{w}-\mathrm{sh}, 1385 \mathrm{w}$, 1364w, 1332w-m, 1258w, 1200w-m, 1105w, 1061m, 953m, 944m-sh $(\mathrm{Nb}=\mathrm{O}), 932 \mathrm{~m}, 920 \mathrm{~m}$, $869 \mathrm{~s}-\mathrm{br}, 809 \mathrm{vs}, 755 \mathrm{~s}, 721 \mathrm{~m}, 676 \mathrm{~m} \mathrm{~cm}^{-1}$.

\subsection{X-ray crystallography}

Crystal data and collection details for $\mathbf{1} \cdot(1 / 2$ toluene) are reported in Table 3. Data were recorded on a Bruker APEX II diffractometer equipped with a CCD detector using Mo-K $\alpha$ radiation. Data were corrected for Lorentz polarization and absorption effects (empirical absorption correction SADABS) [23]. The structure was solved by direct methods and refined by full-matrix leastsquares based on all data using $F^{2}$ [24]. Hydrogen atoms were fixed at calculated positions and refined by a riding model. All non-hydrogen atoms were refined with anisotropic displacement parameters. 


\begin{tabular}{ll} 
Formula & $\mathrm{C}_{61} \mathrm{H}_{80} \mathrm{~F}_{6} \mathrm{~N}_{4} \mathrm{Nb}_{2} \mathrm{O}_{2}$ \\
$\mathrm{FW}$ & 1201.11 \\
$\mathrm{~T}, \mathrm{~K}$ & $100(2)$ \\
$\lambda, \AA$ & 0.71073 \\
Crystal system & Monoclinic \\
Space group & $\mathrm{P} 2_{1}$ \\
$a, \AA$ & $12.674(2)$ \\
$b, \AA$ & $14.382(3)$ \\
$c, \AA$ & $16.854(3)$ \\
$\beta, \circ$ & $106.176(2)$ \\
Cell Volume, $\AA^{3}$ & $2950.4(9)$ \\
$\mathrm{Z}$ & 2 \\
$D_{c}, \mathrm{~g}^{\circ} \mathrm{cm}^{-3}$ & 1.352 \\
$\mu$, mm & \\
$\mathrm{F}(000)$ & 0.452 \\
Crystal size, mm & 1252 \\
Reflections collected & $0.21 \times 0.16 \times 0.12$ \\
Independent reflections & 33235 \\
Data / restraints /parameters & $13717\left[\mathrm{R}_{\text {int }}=0.0270\right]$ \\
Goodness on fit on F $\mathrm{F}^{2}$ & $13717 / 1 / 693$ \\
$R_{1}(I>2 \sigma(I))$ & 1.038 \\
$w R_{2}($ all data $)$ & 0.0242 \\
Largest diff. peak and hole, e $\AA^{-3}$ & 0.0579 \\
\hline
\end{tabular}

\subsection{Computational studies}

The computational geometry optimizations were carried out without symmetry constrains, using the range-separated DFT functional $\omega \mathrm{B} 97 \mathrm{X}$ [25] in combination with the split-valence polarized basis set of Ahlrichs and co-workers (with ECP on the niobium centres) [26]. The C-PCM implicit solvation model $(\varepsilon=9.08)$ was added [27]. The "restricted" formalism was applied. The software used was Gaussian '09 [28].

Supporting Information. DFT-optimized structures are collected in a separated .xyz file. CCDC 1468228 contains the supplementary crystallographic data for $\mathbf{1}$. These data can be obtained free of charge via http://www.ccdc.cam.ac.uk/conts/retrieving.html, or from the Cambridge Crystallographic Data Centre, 12 Union Road, Cambridge CB2 1EZ, UK; Fax: (+44) 1223336 033; or E-mail: deposit@ccdc.cam.ac.uk.

\section{Acknowledgements}

We thank the University of Pisa for financial support. 


\section{References}

[1] See for instance:

(a) F. Lazreg, F. Nahra, C. S. J. Cazin. Coord. Chem. Rev., 293-294, 58 (2015).

(b) J. A. M. Lummiss, C. S. Higman, D. L. Fyson, R. McDonald, D. E. Fogg. Chem. Sci., 6, 6739 (2015).

(c) J. Broggi, V. Jurcík, O. Songis, A. Poater, L. Cavallo, A. M. Z. Slawin, C. S. Cazin. J. Am. Chem. Soc., 135, 4588 (2013).

(d) J. DePasquale, M. Kumar, M. Zeller, E. T. Papish. Organometallics, 32, 966 (2013).

(e) K. F. Donnelly, A. Petronilho, M. Albrecht. Chem. Commun., 49, 1145 (2013).

(f) L. Oehninger, R. Rubbiani, I. Ott. Dalton Trans., 42, 3269 (2013).

(g) H. Diaz Velazquez, F. Verpoort. Chem. Soc. Rev., 41, 7032 (2012).

(h) K. M. Hindi, M. J. Panzner, C. A. Tessier, C. L. Cannon, W. J. Youngs. Chem. Rev., 109, 3859 (2009).

[2] S. Bellemin-Laponnaz, S. Dagorne. Chem. Rev., 114, 8747 (2014).

[3] (a) C. A. Dodds, M. D. Spicer, T. Tuttle. Organometallics, 30, 6262 (2011).

(b) C. Lorber, L. Vendier. Dalton Trans., 6972 (2009).

[4] (a) M. Bortoluzzi, E. Ferretti, F. Marchetti, G. Pampaloni, S. Zacchini. Chem. Commun., 50, 4472 (2014).

(b) M. Bortoluzzi, E. Ferretti, F. Marchetti, G. Pampaloni, S. Zacchini. Dalton Trans., 45, 6939 (2016).

(c) M. Bortoluzzi, E. Ferretti, F. Marchetti, G. Pampaloni, S. Zacchini. Inorg. Chem., 55, 4173 (2016).

[5] (a) D. Pugh, J. A. Wright, S. Freeman, A. A. Danopoulos. Dalton Trans., 775 (2006). 
(b) W. A. Herrmann, K. Öfele, M. Elison, F. E. Kühn, P. W. Roesky. J. Organomet. Chem., 480, C7 (1994).

(c) Z. Hong Wei, W. Zhang, G. Luo, F. Xu, Y. Xuan Mei, H. Cai, New J. Chem., DOI 10.1039/c6nj00223d

[6] (a) C. D. Abernethy, G. M. Codd, M. D. Spicer, M. K. Taylor. J. Am. Chem. Soc., 125, 1128 (2003).

(b) W. A. Herrmann, G. M. Lobmaier, M. Elison. J. Organomet. Chem., 520, 231 (1996).

[7] (a) M. Bortoluzzi, M. Hayatifar, F. Marchetti, G. Pampaloni, S. Zacchini. Inorg. Chem., 54, 4047 (2015).

(b) F. Marchetti, G. Pampaloni, S. Zacchini. RSC Adv., 4, 60878 (2014).

(c) F. Marchetti, G. Pampaloni, C. Pinzino. Chem. Eur. J., 19, 13962 (2013).

(d) F. Marchetti, G. Pampaloni. Chem. Commun., 48, 635 (2012), and references therein.

(e) F. Marchetti, C. Pinzino, S. Zacchini, G. Pampaloni. Angew. Chem. Int. Ed., 49, 5268 (2010).

[8] (a) S. M. Coman, M. Verziu, A. Tirsoaga, B. Jurca, C. Teodorescu, V. Kuncser, V. I. Parvulescu, G. Scholz, E. Kemnitz. ACS Catal., 5, 3013 (2015).

(b) Y. Satoh, Y. Obora. Eur. J. Org. Chem., 5041 (2015).

(c) M. E. Wilhelm, M. H. Anthofer, R. M. Reich, V. D'Elia, J.-M. Basset, W. A. Herrmann, M. Cokoja, F. E. Kühn. Catal. Sci. Technol., 4, 1638 (2014).

(d) A. Monassier, V. D'Elia, M. Cokoja, H. Dong, J. D. A. Pelletier, J.-M. Basset, F. E. Kühn. ChemCatChem, 5, 1321 (2013).

(e) C. Redshaw, M. Walton, L. Clowes, D. L. Hughes, A.-M. Fuller, Y. Chao, A. Walton, V. Sumerin, P. Elo, I. Soshnikov, W. Zhao, W.-H. Sun. Chem. Eur. J., 19, 8884 (2013).

(f) A. M. Raspolli Galletti, G. Pampaloni. Coord. Chem. Rev., 254, 525 (2010). 
(g) K. Fuchibe, T. Kaneko, K. Mori, T. Akiyama. Angew. Chem. Int. Ed., 48, 8070 (2009).

(h) S. S. Kim, G. Rajagopal, S. C. George, Appl. Organomet. Chem., 21, 368 (2007).

[9] V. C. Gibson, T. P. Kee, A. Shaw. Polyhedron, 7, 2217 (1988).

[10] (a) W. Levason, G. Reid, J. Trayer, W. Zhang. Dalton Trans., 43, 3649 (2014).

(b) M. Bortoluzzi, F. Ghini, M. Hayatifar, F. Marchetti, G. Pampaloni, S. Zacchini. Eur. J. Inorg. Chem., 3112 (2013).

(c) V. C. Gibson, T. P. Kee. J. Chem. Soc., Dalton Trans., 1657 (1993).

(d) L. G. Hubert-Pfalzgraf, A. A. Pinkerton. Inorg. Chem., 16, 1895 (1977).

[11] D. V. Drobot, E. V. Pisarev. Russ. J. Inorg. Chem., 26, 1 (1981).

[12] (a) W. Levason, G. Reid, W. Zhang. J. Fluorine Chem., 172, 62 (2015).

(b) J. Köhler, A. Simon, L. van Wüllen, S. Cordier, T. Roisnel, M. Poulain, M. Somer. Z. Anorg. Allg. Chem., 628, 2683 (2002).

(c) J. Sala-Pala, J. Y. Calves, J. E. Guerchais. J. Inorg. Nucl. Chem., 37, 1294 (1975).

[13] (a) S. L. Benjamin, W. Levason, G. Reid. Chem. Soc. Rev., 42, 1460 (2013).

(b) A. Agulyansky. "Chemistry of Tantalum and Niobium Fluoride Compounds", Elsevier, Amsterdam, 1st Ed. (2004).

[14] (a) M. Hayatifar, F. Marchetti, G. Pampaloni, S. Zacchini. Polyhedron, 70, 6 (2014).

(b) M. Jura, W. Levason, G. Reid, M. Webster. Dalton Trans., 7610 (2009).

[15] Niobium oxide trifluoride has a $3 \mathrm{D}$ polymeric structure in the solid state $\left(\mathrm{SnF}_{4}\right.$ type structure, ref. 12b), while niobium pentafluoride is tetranuclear [A. J. Edwards. J. Chem. Soc., 3714 (1964)]. These compounds will be mentioned by the respective empirical formulas, i.e. $\mathrm{NbF}_{5}$ and $\mathrm{NbOF}_{3}$, throughout this paper.

[16] (a) S. L. Benjamin, A. Hyslop, W. Levason, G. Reid. J. Fluorine Chem., 137, 77 (2012).

(b) M. Jura, W. Levason, R. Ratnani, G. Reid, M. Webster. Dalton Trans., 39, 883 (2010). 
[17] K. F. Hirsekorn, A. S. Veige, M. P. Marshak, Y. Koldobskaya, P. T. Wolczanski, T. R. Cundari, E. B. Lobkovsky. J. Am. Chem. Soc., 127, 4809 (2005).

[18] (a) G. S. McGrady, A. Haal,, H. P. Verne, H. V. Volden, A. J. Downs, D. Shorokhov, G. Eickerling, W. Scherer. Chem. Eur. J., 11, 4921 (2005).

(b) N. C. Tomson, J. Arnold, R. G. Bergman. Organometallics, 29, 2296 (2010).

(c) M. Schormann, S. P. Varkey, H. W. Roesky, M. Noltemeyer. J. Organomet. Chem., 621, $310(2001)$.

[19] A. Bondi. J. Phys. Chem., 68, 441 (1964).

[20] A. Doddi, C. Gemel, R. W. Seidel, M. Winter, R. A. Fischer. Polyhedron, 52, 1103 (2013).

[21] The geometry optimization was carried out without symmetry constrains. However, the optimized geometry showed approximate C2 symmetry; the bond lengths and angles in Table 2 are the same for both the fragments within the significant digits.

[22] (a) A. J. Arduengo, III, R. Krafczyk, R. Schmutzler, H. A. Craig, J. R. Goerlich, W. J. Marshall, M. Unverzagt. Tetrahedron, 55, 14523 (1999).

(b) L. Hintermann. Beilst. J. Org. Chem., 3 (2007), doi:10.1186/1860-5397-3-22.

[23] G. M. Sheldrick. SADABS, Program for empirical absorption correction, University of Göttingen, Germany (1996).

[24] G. M. Sheldrick. SHELX97, University of Göttingen, Göttingen, Germany (1997).

[25] (a) Y. Minenkov, Å. Singstad, G. Occhipinti, V. R. Jensen. Dalton Trans., 41, 5526 (2012).

(b) J.-D. Chai, M. Head-Gordon. Phys. Chem. Chem. Phys., 10, 6615 (2008).

(c) I. C. Gerber, J. G. Ángyán. Chem. Phys. Lett., 415, 100 (2005).

[26] F. Weigend, R. Ahlrichs. Phys. Chem. Chem. Phys., 7, 3297 (2005).

[27] (a) V. Barone, M. Cossi. J. Phys. Chem. A, 102, 1995 (1998).

(b) M. Cossi, N. Rega, G. Scalmani, V. Barone. J. Comput. Chem., 24, 669 (2003). 
[28] Gaussian 09, Revision C.01, M. J. Frisch et al., Gaussian, Inc., Wallingford CT (2010). 